九州大学学術情報リポジトリ

Kyushu University Institutional Repository

\title{
Difference of Xanthomonas campestris Strains Isolated from Soybean, Cowpea and Mung Bean in Pathogenicity and Bacteriological Properties
}

Jainkittivong, Anong

Plant Pathology Laboratory, Faculty of Agriculture, Kyushu University

Tsuchiya, Kenichi

Plant Pathology Laboratory, Faculty of Agriculture, Kyushu University

Matsuyama, Nobuak i

Plant Pathology Laboratory, Faculty of Agriculture, Kyushu University

Wakimoto, Satoshi

Plant Pathology Laboratory, Faculty of Agriculture, Kyushu University

https://doi.org/10.5109/23942

出版情報 : 九州大学大学院農学研究院紀要. 33 (3/4)，pp. 305-314，1989-03. Kyushu University バージョン：

権利関係： 


\title{
Difference of Xanthomonas campestris Strains Isolated from Soybean, Cowpea and Mung Bean in Pathogenicity and Bacteriological Properties
}

\author{
Anong J ainkittivong, Kenichi Tsuchiya*, Nobuaki M atsuyama \\ and Satoshi W akimoto
}

Plant Pathology Laboratory, Faculty of Agriculture Kyushu University 46-01, Fukuoka 812, Japan.

(Received November 30, 1988)

\begin{abstract}
Fourty-eight bacterial strains were isolated from the leaves of pustule infected soybean and blight infected cowpea and mung bean collected from Japan and Thailand. These strains were devided into 3 pathovars. Twenty-seven strains isolated from soybean caused severe pustule on soybean leaves but very slight symptom of blight on cowpea and mung bean suggesting that they belonged to Xanthomonas campestris pv. glycines. Among 15 strains isolated from cowpea, 14 strains showed severe symptom on cowpea and slight symptom on soybean and mung bean suggesting that these strains belonged to X. c. pv. vignicoh. One strains was not pathogenic to cowpea but to mung bean slightly. Six strains isolated from mung bean were strongly pathogenic to mung bean but slightly to soybean and not pathogenic to cowpea. These strains belonged to X. c. pv. phaseoli. These 3 pathovars are similar in most of the bacteriological properties tested but different each other in such properties as utilization of glycogen, maltose, D-ribose and $\mathrm{D}+$ melibiose. X. c. pv. glycines and X.c.pv. phaseoli were serologically identical while they were different from $X$.c. pv. vignicoh
\end{abstract}

\section{INTRODUCTION}

The bacterial strains belonging to xanthomonads are difficult to identify because of their similarity in morphological, biological and physiological properties (Wolf, 1924). At present, strains of Xanthomonas campestris are differentiated into pathovars depending upon their pathogenicity to various plants (Young et al., 1978, Dye et al., 1980, Fahy and Persley, 1983, Bradbury, 1986). X. c. pv. glycines is considered to be almost similar to X. c. pv. vignicola and X. c pv. phaseoli in bacteriological properties with only exception in pathogenicity (Jindal et al., 1981). The former is pathogenic to soybean while the latters are to cowpea and mung bean, respectively.

The purpose of this study was to clarify whether or not the xanthomonads isolated from soybean, cowpea and mung bean grown in Japan and Thailand are possible to be differentiated into X. c. pv. glycines, pv. vignicokz and pv. phaseoli. The relationships among pathogenicity and bacteriological properties were also examined.

\section{MATERIALS AND METHODS}

Bacterial strains : The bacterial strains were isolated from pustule infected soybean leaves and blight infected cowpea and mung bean leaves collected from

*Present address : National Institute of Agro-environment Sciences, Tsukuba, Ibaraki 305 
Thailand and Japan. Bacterial strains cultured on the slants of PSA medium (potato decoction 1 liter/300 g, $\mathrm{Na}_{2} \mathrm{HPO}_{4} \cdot 12 \mathrm{H}_{2} \mathrm{O} 2 \mathrm{~g}, \mathrm{Ca}\left(\mathrm{No}_{3}\right)_{2} 0.5 \mathrm{~g}$, peptone $5 \mathrm{~g}$, sucrose 15 $\mathrm{g}$, agar $15 \mathrm{~g}, \mathrm{pH}$ 7.0) were maintained at 4C for ordinary use (Misra and Thapliyal, 1977). The culture were lyophilized with PS liquid medium and maintained at 4C for long term preservation.

To determine whether xanthomonads can clearly be differentiated or not, cross inoculation test was done against the following soybean, cowpea and mung bean cultivars.

Soybean cultivars : Hyuga and Akiyoshi from Japan and S. J. 4, S. J. 5, OCB and 81-l-032 from Thailand.

Cowpea cultivars: Akadane sanjaku, Kurodane sanjaku, Peking sanjaku and Kegonnotaki from Japan.

Mung bean cultivars : Kampengsean 1, Kampengsean 2 and Uthong from Thailand.

Pathogenicity test : Pathogenicity of the bacterial strain was tested by spray inoculation. The bacterial cells grown on the slant of PSA medium at 30C for $48 \mathrm{hr}$ were suspended in $0.1 \% \mathrm{NaCl}$ and centrifuged at $10,000 \mathrm{rpm}$ for $10 \mathrm{~min}$. The precipitate was suspended in distilled water to adjust bacterial concentration to approximately $10^{7}-10^{8} \mathrm{cfu} / \mathrm{ml}$ (OD 0.1 at $660 \mathrm{~nm}$ ). Inoculum thus prepared was sprayed to various cultivars of soybean, cowpea and mung bean. Both lower and upper surfaces of primary and trifoliated leaves of 3 -week old healthy plants were inoculated. The inoculated plants were kept overnight in an incubator at 28-30 C, RH $=100 \%$, and transferred to the greenhouse, the temperature of which was controlled at 22-25 C. The results were recorded as - to $\mathrm{Wl}$ according to the following standards, 3, 7 and 14 days after inoculation.

- : No symptom appeared.

$+\sim$ m: The disease severity was expressed by the number of + as shown in Fig. 1.

\section{Physiological and biological properties of bacterial strains}

Criteria for differentiating xanthomonads followed the 9th Ed. of Bergey's Mannual of Determinative Bacteriology. On the basis of the ability to grow at $36 \mathrm{C}$, esculin hydrolysis, mucoid growth, gelatin liquefaction, urease production, protein

Table 1. Xanthomonas campestris strains used in this experiment

\begin{tabular}{|c|c|c|c|}
\hline $\begin{array}{c}\text { Xan thomonas campestris } \\
\text { strain }\end{array}$ & Host & Place & Year \\
\hline $\begin{array}{l}\mathbf{0 4 5}(-1,-4,-8) \\
\mathbf{0 4 6 - 3} \\
\mathbf{0 5 4}(-1,-2,-4) \\
\mathbf{3 0 1}(-1,-4,-5,-7,-8) \\
\mathrm{Ku}(-1,-2) \\
\text { s }(-1 \sim-13) \\
267(-1,-5 \sim-7,-9,-10) \\
268(-3,-9,-10) \\
317(-2,-5 \sim-8,-10) \\
318(-2 \sim-7)\end{array}$ & $\begin{array}{c}\text { Soybean } \\
\prime \prime \\
\prime \prime \\
\prime \prime \\
\prime \prime \\
\prime \prime \\
\text { Cowpea } \\
\prime \prime \\
\prime \prime \\
\text { Mung bean }\end{array}$ & 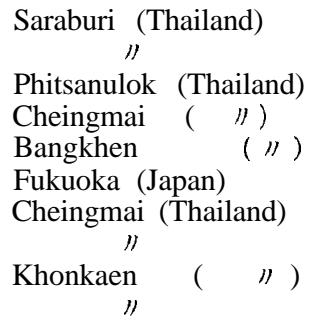 & $\begin{array}{c}1980 \\
\text { "1 } \\
\text { " } \\
1981 \\
1982 \\
1986 \\
1981 \\
\text { JJ }\end{array}$ \\
\hline
\end{tabular}



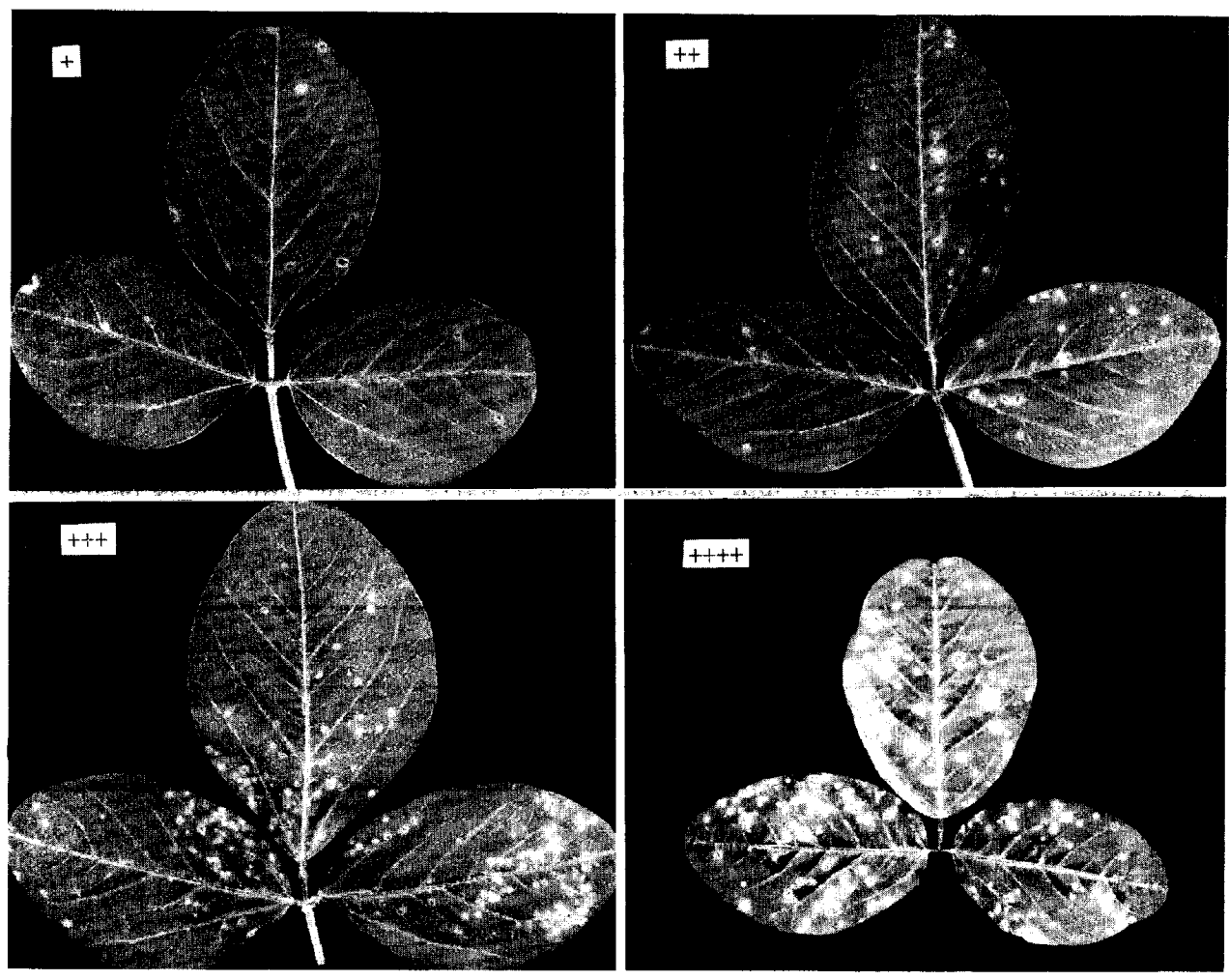

Fig. 1. Standard for evaluating disease severity.

digestion, catalase, $\mathrm{H}_{2} \mathrm{~S}$ from peptone, oxidase, nitrate reduction, hydrolysis of Tween 80 , indole production, utilization of carbon sources (acetate, lactate, succinate, malonate, formate, tartrate, benzoate) and acid production from carbohydrates (arabinose, glucose, mannose, galactose, lactose, $\mathrm{D}$ +cellobiose, maltose, D-xylose, D-ribose, raffinose, glycogen, D+melezitose, adonitol, mannitol, sorbitol, rhamnose, salicin, inulin, $\alpha$-methylglycoside, inositol) were tested.

\section{Serological properties of bacterial strains}

Antisera: Two strains of X. campestris, S-12 and 318-2, were used to produce antisera. Each strain was cultured on a slant of PSA medium for $24 \mathrm{hr} 30 \mathrm{C}$, suspended into $10 \mathrm{ml}$ of $0.85 \% \mathrm{NaCl}$ solution and washed twice by centrifugation at $8,000 \mathrm{rpm}, 20$ min. The precipitant was resuspended in $0.85 \% \mathrm{NaCl}$ solution at approximately $10^{6}$ $\mathrm{cfu} / \mathrm{ml}$. The bacterial suspension thus prepared was intravenously injected 6 times periodically at 4 days intervals to the New Zealand rabbit with increasing doses from $0.5 \mathrm{ml}$ to $2 \mathrm{ml}$.

Antigens: All bacterial strains shown in Table 1 were used as antigens to test their reaction against antisera. Some bacterial strains (Table 2) which are not originated from soybean, cowpea and mung bean were also used as antigen to test serological relationship. The suspension of each bacterium, the concentration of which 
Table 2. Bacterial strains additionally used as antigens for serological test.

\begin{tabular}{ll}
\multicolumn{1}{c}{ Bacteria } & \multicolumn{1}{c}{ Strains } \\
\cline { 2 - 2 } Xanthomonas campestris pv. oryzae & H75373, T7133, T7147, TB7816, H75304 \\
X. c. pv. campestris & 1,111 \\
X. c. pv. pisi & $\mathrm{L}-1$ \\
X. c. pv. citri & $1-1-3$ \\
Peudomonas glumae & PAF, PT102 \\
P. gladioli pv. gladioli & NIAES 1065 \\
P. cepacia & $342-43$ \\
Erwinia carotovora subsp. carotovora & 8415 \\
E. chrysanthemi & ICHI-1, R-8, Ku8601, Ku8609 \\
Corynebacterium michiganense pv. michiganense & \\
\hline
\end{tabular}

was adjusted to ca. $10^{6} \mathrm{cfu} / \mathrm{ml}$, was devided into 2 parts, one of which was heated at $100 \mathrm{C}$ for $10 \mathrm{~min}$ and the other was not heated.

Agar gel diffusion test : The Ouchterlony double diffusion method was used. The antiserum was dropped in the center well and antigens were in the surrounding wells. The plates thus prepared were incubated at room temperature $(20-25 \mathrm{C})$ for $24 \mathrm{hr}$. The precipitin bands were observed against light in the dark room.

\section{RESULTS}

\section{Pathogenicity of bacterial strains}

The pathogenicity of bacterial strains on the leaves of soybean, cowpea and mung bean is as shown in Table 3. Pathogenic variation was clearly shown among $X$. campestris strains. All strains isolated from soybean caused severe symptom to most of the soybean cultivars used (Table 3). The first sign of infection usually appeared as pale-green spots with elevated center within 1 to 3 days after inoculation. They developed into irregular or sometimes round having reddish-brown center with yellowish halo within 10 days after inoculation.

The majority of bacterial strains from soybean did not show pathogenicity on the cowpea and mung bean cultivars. However, the strains $045-1$ and $301-8$ produced a few blight spot on cowpea and mung bean leaves.

Almost all strains isolated from cowpea and mung bean did not show any symptom on soybean with exception of the strains 267-6, 267-10 and 318-5 which produced a few number of pustules with halo on the leaf blade one week after inoculation (Table 3). The mung bean cultivars Kampengsean 2 was affected with many bacterial strains isolated from soybean and cowpea but the symptom developed very slowly with no evidence of pustule formation (Table 4).

The strains 267-1 to 267-10 isolated from cowpea showed an ability to severely infect cowpea and slightly infect mung bean, while others such as 268-3 to 268-10 and 317-2 to 317-10 infect only cowpea. The strains 318-2 to 318-7 isolated from mung bean also infected only mung bean showing symptom within 2-3 days after inoculation. The symptom is whitish raised blisters different from the pustules caused by the bacteria isolated from soybean. The spots turned to brown and necrotic spots within 4-7 days.

Most of the strains isolated from soybean showed strong pathogenicity to all 
soybean cultivars used. However, there were some isolates which could not attack cultivar Hyuga or OCB suggesting differentiation of bacterial strains in pathogenicity.

From these results, X. campestris strains isolated from soybean, cowpea and mung bean could be grouped into 3 pathovars of glycines, vignicola and phaseoli, respectively.

\section{Physiological and biochemical properties of bacterial strains}

Considerable variation was observed among individual strains in such properties as urease activity, growth at $36 \mathrm{C}$, hydrolysis of Tween 80 and acid production from mannose, D + cellobiose, maltose, D- xylose, D - ribose, D + melibiose, raffinose, glycogen and mannitol (Table 5).

All strains isolated from soybean and mung bean produced acid from maltose but most of those from cowpea did not. More than half of the strains from soybean and cowpea produced acid from D-ribose but most strains from mung bean did not. $65 \%$ of the strains from soybean produced acid from $\mathrm{D}+$ melibiose, $60 \%$ of the strains from cowpea and all of the strains from mung bean did not produce acid from D+melibiose.

All strains from cowpea and mung bean did not produce acid from glycogen but most of the strains from soybean showed positive result.

All strains produced acid from arabinose, glucose and galactose within 2-7 days. Almost all strains also produced acid from mannose, D+cellobiose, D-xylose, and D-ribose. More than half of the strains did not produced acid from D+melibiose raffinose and mannitol. However none of the strains did not utilize lactose, D +

Table 3. Comparison of Xanthomonas campestris strains isolated from soybean, cowpea and mung bean in the pathogenicity to soybean cultivars.

\begin{tabular}{|c|c|c|c|c|c|c|c|}
\hline \multirow{2}{*}{ Bacterial strains } & & \multicolumn{6}{|c|}{ Soybean cultivars } \\
\hline & & Hyuga & Akiyoshi & $\mathrm{OCB}$ & $81-1-032$ & S. J. 4 & S.J. 5 \\
\hline \multicolumn{8}{|l|}{ From soybean } \\
\hline 045-1 & & Ht & \# & + & WI & 册 & m \\
\hline $301-4,301-8$, S-1 & $\longrightarrow$ & H & H & H & m & H & \# \\
\hline $045-8,046-3,301-5$, & $\longrightarrow$ & & & & & & \\
\hline S-2, S-6-S-9 & & Hit & \# & & \# & H & m \\
\hline $054-2$ & & H & m & + & m & m & m \\
\hline 054-1 & & H & H & \# & H & H & Ht \\
\hline $301-7$, s-10-s-12 & & \# & H & \# & WH & 曲 & $\mathrm{H}$ \\
\hline $\mathrm{Ku}-1$ & & & $H$ & \# & H & H & \# \\
\hline $\mathrm{Ku}-2$ & & - & \# & H & H & H & \# \\
\hline$s-3-s-5$ & & H & H & H & 曲 & 册 & H曲 \\
\hline s-13 & & m & 曲 & + & 曲 & H & 曲 \\
\hline \multicolumn{8}{|l|}{ From cowpea } \\
\hline $267-1,267-5$, & & & & & & & \\
\hline $267-7,267-9$ & & & - & & & & - \\
\hline $267-6, \quad 267-10$ & & + & & + & & + & + \\
\hline $268-3,268-9,268-10$ & & - & - & & - & & \\
\hline $317-2,317-5,317-6$, & $\longrightarrow$ & & & & & & \\
\hline $317-7,317-8,317-10$ & & - & & & & & \\
\hline \multicolumn{8}{|l|}{ From mung bean } \\
\hline $\begin{array}{l}318-6-518-4 \\
318-6, \quad 318-7\end{array}$ & & - & & & & & \\
\hline $318-5$ & & + & & & & + & \\
\hline
\end{tabular}

$-\quad=$ Immune $\quad+\sim$ 册 $=$ Disease severity 
Table 4. Comparison of Xanthomonas campestris strains isolated from soybean, cowpea and mung bean in the pathogenicity to cowpea and mung bean.

\begin{tabular}{|c|c|c|c|c|c|c|c|c|}
\hline \multirow[b]{3}{*}{ Bacterial strains } & & \multicolumn{7}{|c|}{ Pathogenicity } \\
\hline & & \multicolumn{4}{|c|}{ Cowpea } & \multicolumn{3}{|c|}{ Mung bean } \\
\hline & & 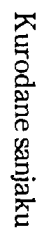 & 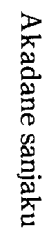 & 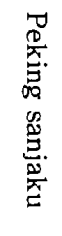 & 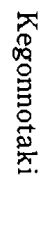 & 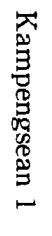 & 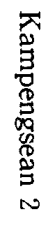 & 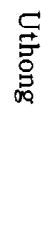 \\
\hline \multicolumn{9}{|l|}{ From soybean } \\
\hline $\begin{array}{l}045-1 \\
045-4\end{array}$ & & + & + & + & + & & $\begin{array}{l}+ \\
+\end{array}$ & \\
\hline BA6-8, 854-\$,-105,4-3,01-7 & $\square$ & - & - & - & - & - & + & - \\
\hline В96-5, Ba1-2, 301-4, & 7 & - & - & - & - & - & - & - \\
\hline $\begin{array}{l}301-8 \\
\text { From cowpea }\end{array}$ & & + & + & + & + & & + & + \\
\hline $\begin{array}{l}267-\Phi, \quad 267-\$ 0 \text { 267-7, } \\
267-6\end{array}$ & 7 & - & - & \# & H & $\begin{array}{l}+ \\
+\end{array}$ & $\begin{array}{l}+ \\
+\end{array}$ & $\begin{array}{l}+ \\
+\end{array}$ \\
\hline 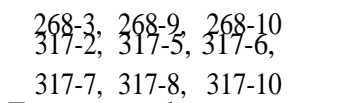 & 7 & & & \# & \# & - & - & \\
\hline $\begin{array}{l}\text { From mung bean } \\
318-2,318-3 \text {, } \\
318-5,318-7\end{array}$ & & - & - & - & - & W & H & m \\
\hline
\end{tabular}

$$
-\quad=\text { Immune } \quad+\sim \text { W }=\text { Disease severity }
$$

melezitose, adonitol, sorbitol, rhamnose, salicin, inulin, a-methylglycoside and inositol. The sodium salts of organic acids such as acetate, lactate, succinate, malonate, formate, benzoate were utilized completely but tartrate was not (data not shown).

The above mentioned variations were similarly observed in both Japanese and Thai strains with some exceptions. Most of Thai strains could grow at $36 \mathrm{C}$ but only $54 \%$ of Japanese strains could. Only $31 \%$ of Thai strains could utilize mannitol and produced acid, while $54 \%$ of Japanese strains could.

\section{Serological properties of bacterial strains}

When living whole cells were used as antigens, both X. c. pv. glycines and X. c. pv. phaseoli strains produced one band (a) against anti-S-12 serum and two bands (a, b) against anti-318-2 serum. However, X. c. pv. vignicolu only produced band b with anti -318-2 serum. When heated antigens were used, the band $\mathrm{b}$ disappeared (Fig. 2-A, $\mathrm{B}$ and Table 6).

None of the bacterial strains listed in Table 2 produced precipitin bands identical to those produced by X. campestris pv. glycines, pv. vignicola and pv. phaseoli. 
Table 5. Comparison of Xanthomonas campestris strains isolated from soybean, cowpea and mung bean in bacteriological properties.

\begin{tabular}{|c|c|c|c|}
\hline \multirow{2}{*}{ Characteristics } & \multicolumn{3}{|c|}{$\begin{array}{l}\text { Xanthomonas campestris pathovars } \\
\text { (No. of strains tested) }\end{array}$} \\
\hline & $\begin{array}{l}\text { pv. glycines } \\
\text { (27) }\end{array}$ & $\begin{array}{l}\text { pv. vignicola } \\
\text { (15) }\end{array}$ & $\begin{array}{l}\text { pv. phaseoli } \\
\text { (6) }\end{array}$ \\
\hline Mucoid growth & + & + & + \\
\hline \multicolumn{4}{|l|}{ Hydrolysis of } \\
\hline Starch & + & + & + \\
\hline Gelatin & + & + & + \\
\hline Esculin & + & + & + \\
\hline Milk proteolysis & + & + & + \\
\hline $\mathrm{H}_{2} \mathrm{~S}$ from peptone & + & + & + \\
\hline Urease activity & $-(91 \%)$ & $-(93 \%)$ & $-(83 \%)$ \\
\hline Growth at $36 \mathrm{C}$ & $+(69 \%)$ & $+(93 \%)$ & $+(66 \%)$ \\
\hline Nitrate reduction & - & - & - \\
\hline Indole production & - & - & - \\
\hline Catalase & + & + & + \\
\hline Oxidase & + & + & + \\
\hline Hydrolysis of Tween 80 & $+(97 \%)$ & $+(96 \%)$ & + \\
\hline \multicolumn{4}{|l|}{ Acid production from } \\
\hline Arabinose & + & + & + \\
\hline Glucose & + & + & + \\
\hline Mannose & $+(91 \%)$ & $+(93 \%)$ & $+(93 \%)$ \\
\hline Galactose & + & + & + \\
\hline $\mathrm{D}+$ Cellobiose & $+(91 \%)$ & $+(87 \%)$ & $+(50 \%)$ \\
\hline Lactose & - & - & - \\
\hline Maltose & + & $-(93 \%)$ & + \\
\hline D-Xylose & $+(91 \%)$ & $+(53 \%)$ & + \\
\hline D-Ribose & $+(78 \%)$ & $+(66 \%)$ & $-(83 \%)$ \\
\hline D + Melibiose & $+(65 \%)$ & $-(60 \%)$ & - \\
\hline Raffinose & $-(000)$ & $-(87 \%)$ & \\
\hline$D+$ Melezitose & & & \\
\hline Glycogen & $+(91 \%)$ & - & - \\
\hline Adonitol & & - & \\
\hline Mannitol & $-(59 \%)$ & - & \\
\hline Sorbitol & - & - & - \\
\hline Rhamnose & & - & - \\
\hline Salicin & - & & - \\
\hline Inulin & - & & \\
\hline$\alpha$-Methylglycoside & - & - & - \\
\hline Inositol & - & - & \\
\hline
\end{tabular}

\section{DISCUSSION}

Fourty-eight bacterial strains isolated from diseased leaves of soybean, cowpea and mung bean collected from Japan and Thailand were clearly differentiated into 3 groups based on their pathogenicity. The results showed that twenty-seven strains including $045(-1,-4,-8), 046-3,054(-1,-2,-4), 301(-1,-4,-5,-7,-8), \mathrm{Ku}$ $(-1,-2)$ and $S(-1 \sim-13)$ caused severe symptom of bacterial pustule only on soybean suggesting that they belonged to X. c. pv. glycines. Other strains including 267 $(-1,-5 \sim-7,-9,-10), 268(-3,-9,-10)$ and $317(-2,-5--8,-10)$ were strongly 

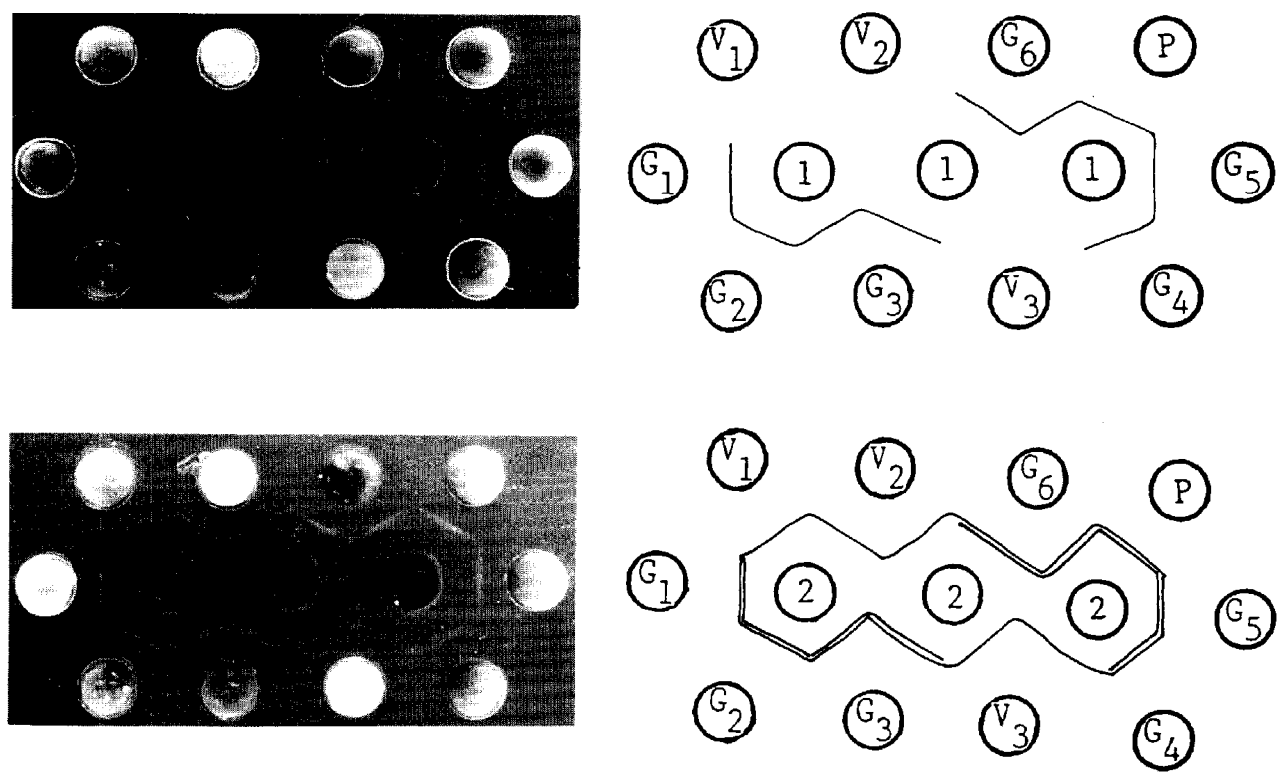

Fig. 2-A. Serological reaction of living whole cell antigens of $X$. campestris strains to antisera against $X$. campestris strains $\mathrm{S}-12$ and 318-2. $\mathrm{G}_{1}, \mathrm{G}_{2}, \mathrm{G}_{3}, \mathrm{G}_{4}, \mathrm{G}_{5}, \mathrm{G}_{6}=$ antigen of the strains 054-1, 046-3, S-12, Ku-I, 045-I and 301-I of $X$. c. pv. glycines, respectively. $V_{1}, V_{2}, V_{3}=$ antigen of strains 267-1, 268-3 and 317-2 of $X$. c. pv. vignicola, respectively. $\mathrm{P}=$ antigen of the strain $318-2$ of $X$. c. pv. phaseoli. $1,2=$ antisera to strains $\mathrm{S}$ -12 and 318-2, respectively.
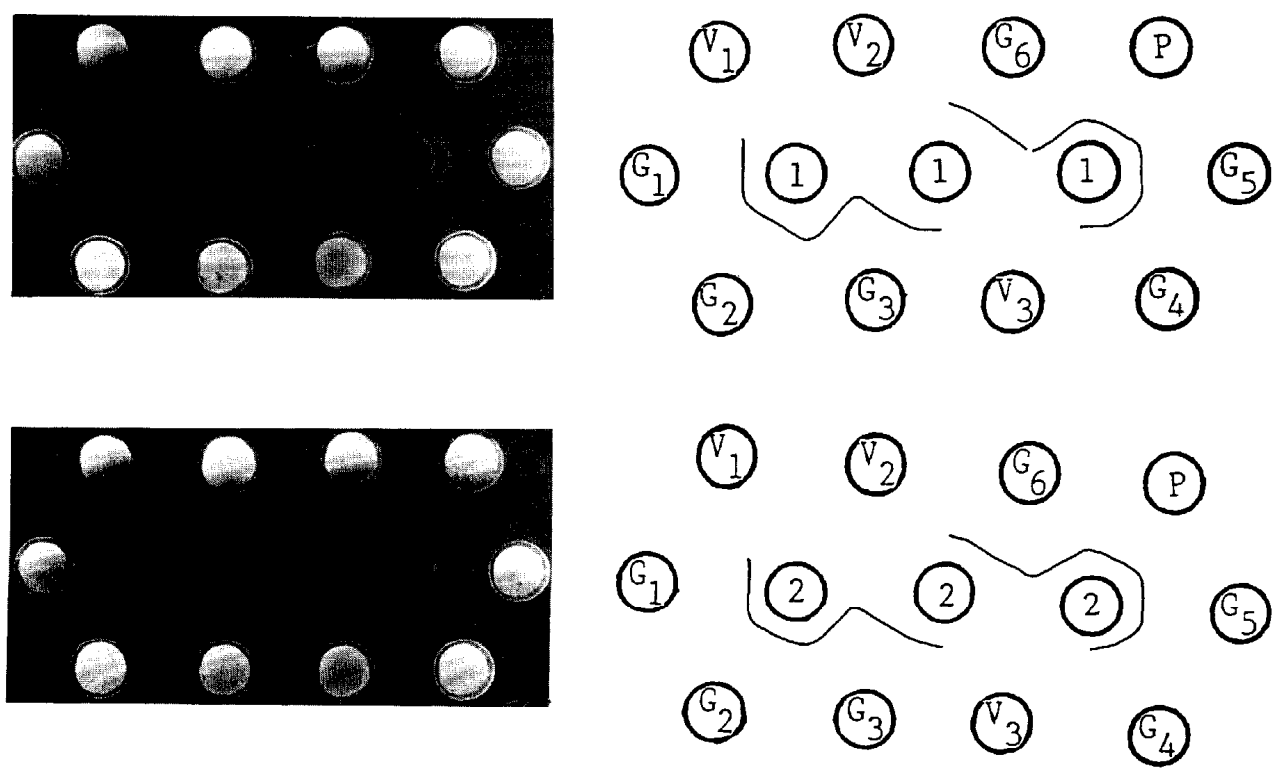

Fig. 2-B Serological reaction of heat killed-cell antigens of X. campestris strains to antisera against X. campestris strains S-12 and 318-2. Symbols: See Fig. 2-A. 
Table 6. Serological reaction of $\mathrm{X}$. campestris pv. glycines, pv. vignicola and pv. phaseoli against anti- $\mathrm{X}$. campestris serum.

\begin{tabular}{|c|c|c|c|c|}
\hline \multirow{3}{*}{ Antigen* } & \multicolumn{4}{|c|}{ Antiserum } \\
\hline & \multicolumn{2}{|c|}{ Living whole cells } & \multicolumn{2}{|c|}{ Heat killed cells } \\
\hline & s-12 & $318-2$ & s-12 & $318-2$ \\
\hline$X$. c. pv. glycines & $\mathrm{a}$ & $\mathrm{ab}$ & $\mathrm{a}$ & $\mathrm{a}$ \\
\hline$X$. c. pv. vignicola & & $\mathrm{b}$ & $-m$ & - \\
\hline X. c. pv. phuseoli & $\mathrm{a}$ & $a b$ & $\mathrm{a}$ & $\mathrm{a}$ \\
\hline
\end{tabular}

* All strains belonging to each pathovar shown in Table. 1. were used.

$-=$ Negative reaction

pathogenic only to cowpea suggesting that they belonged to X. c. pv. vignicola. One strain, 267-6 in Table 4, isolated from cowpea was not pathogenic to cowpea but slightly pathogenic to mung bean. Probably it is an avirulent mutant. The strains isolated from mung bean $318(-2 \sim-7)$ were identified as X. c. pv. phaseoli, as they showed strong pathogenicity only to mung bean. Thus, X.campestris isolated from soybean, cowpea and mung bean were clearly differentiated into three pathovars, viz., pv. glycines, pv. vignicola, and pv. phaseoli (Thakur et al., 1977, Jindal et al. 1981, Jindal and Patel, 1984). These pathovars were very difficult to distinguish from each other by bacteriological properties as Dye (1962) reported previously. However, some minor differences were observed in the utilization of glycogen, maltose, D- ribose and D+ melibiose.

In serological tests using antiserum of X. c. pv. glycines S-12, all of $X$. c. pv. glycines and pv. phaseoli strains reacted producing one band a but not reacted with $X$. c. pv. vignicola strains. When antiserum of X. c. pv. phaseoli 318-2 was used, precipitin bands a and $\mathrm{b}$ were produced with $\mathrm{X}$. c. pv. glycines and pv. phaseoli, but only one precipitin band $\mathrm{b}$ was produced with $\mathrm{pv}$. vignicola. The precipitin band $\mathrm{b}$ is disappeared when heat treated antigens were used. Thus, it will be concluded that X. c. pv. glycines and pv. phaseoli are serologically identical each other but they are different from X. c. pv. vignicola.

\section{REFERENCES}

Bradbury, J. F. 1986 Guide to plant pathogenic bacteria. CAB International mycological institute England, pp. 332

Fahy, P. C. and G. J. Persley 1983 Plant Bacterial Disease: A Diagnostic Guide. pp. 383

Dye, D. W. 1962 The inadequacy of the usual determinative tests for the identification of Xanthomonas spp. New Zealand J. Agri. Res., 29 (2) : 57-67

Dye, D. W., J. F. Bradbury, M. Goto, A. C. Hayward, R. A. Lelliott and N. Schroth 1980 International standard for naming pathovar of phytopathogenic bacteria and a list of pathovar names and pathotype strains. Review of Plant Pathology., 59: 153-159

Jindal, J. K., P. N. Pate1 and A. M. Khan 1981 Variability in xanthomonads of Grain Legumes II. Pathogenic variability in Xanthomonas phaseoli mung bean strains, X. vignicola and X. phaseoli var. sojense. Phytopath. Z., 100: 1-9

Jindal, J. K. and P. N. Pate1 1984 Variability in xanthomonads of grains legumes. IV. Variation in bacteriological properties of 83 isolates and pathogenic behavior of culture variants. Phytopath. 
Z., 110: 63-68

Krieg, N. R., J. G. Hott., (Eds). 1984 Bergey's manual of Systematic Bacteriology. 9th ed., Williams and Wilkins Co. Baltimore 1, pp. 964

Misra, B. C. and P. N. Thappliyal 1977 In vitro growth and nutrition of Xanthomonas phaseoli var. sojense, the causal organism of bacterial pustule of soybean. Indian Phytopath., $30: 388391$

Thakur, R. P., P. N. Pate1 and J. P. Verma 1977 Studies on resistance in crops to bacterial diseases in India. XI Genetic make-up of mung bean differential of the races of bacterial leaf spot pathogen, Xanthomonas phaseoli. Indian Phytopath., 30 : 217-221

Wolf, F. A. 1924 Bacterial pustule of soybean. J. of Agri. Res. 29 : 57-68

Young, J. M., D. W. Dye., J. F. Bradbury, C. G. Pangopoulos and C. F. Robbs 1978 A proposed nomenclature and classification for plant pathogenic bacteria. New Zealand J.Agric. Res., 21 : 153-177 